\title{
The Motivation of SMEs to Sale Online in Market Place to Increase Sales Performances
}

\author{
Saryadi $^{1}$, Robetmi Jumpakita Pinem ${ }^{2}$ \\ \{robetmi@lecturer.undip.ac.id²\} \\ Universitas Diponegoro, Indonesia ${ }^{1,2}$
}

\begin{abstract}
This research aims to find out the motivation of SMEs to make online sales to improve business performance. The development of the internet is so rapid that all of the country. The development and improvement of infrastructure by the government has greatly helped the reach and quality of the internet in Indonesia. Data on internet user penetration shows that the development of the internet in Indonesia continues to experience an increase in users. Currently so many transactions that occur through online, including market places are increasingly popular. The development of the internet has been used extensively by MSMEs in Indonesia. Marketing strategy carried out through the market place is expected to be able to increase MSME sales. This research is analytical descriptive and by in-depth interviews. Primary data, in this study primary data were obtained from the results of in-depth interviews with key people selected for SMEs who sell products online. Secondary data, obtained from documents, regulations and other forms that can provide information related to this research. Coffee businesses run by MSMEs can increase sales after doing online. The comparison that can be done is before making online sales, the real comparison that can be seen is the sale of coffee products which initially only sold $30 \mathrm{~kg}$ a month and increased to $300 \mathrm{~kg}$, about 10 times the initial sales. This shows that the power of going online is a very significant one to increase sales, especially for MSMEs.
\end{abstract}

Keywords: SMEs, Sale, Online, Increase, Performances.

\section{Introduction}

The development of the internet is so rapid that all corners of the country, the development and improvement of infrastructure by the government has greatly helped the reach and quality of the internet in Indonesia. Almost all people can enjoy internet access for information exchange purposes, even the quality of the internet is getting cheaper. More quality so that people in general can feel and use the internet in their daily activities.

Based on the survey results of the Indonesian Internet Service Providers Association (APJII) [1] shows that internet user penetration in Indonesia continues to increase. Data for 2017 internet users reached 143.26 million people or equivalent to $54.7 \%$ of Indonesia's total population and data for 2016132.7 million people. Data on internet user penetration shows that the development of the internet in Indonesia continues to experience an increase in users.

Today everyone is increasingly aware of the importance of the internet as a means of exchanging information in the form of sending messages, sending data, entertainment and even transactions to buy products. The development of the internet that continues to grow day by day is followed by the development of online buying and selling transactions which 
initially only bought and sold are conventional. Currently so many transactions that occur through online, including market places are increasingly popular. The development of the internet has been used extensively by Micro, Small and Medium Enterprises (MSMEs) in Indonesia, including Blora Regency, Central Java. MSMEs in Blora Regency are already marketing products through market places such as Tokopedia, Bukalapak and other market places. The marketing strategy carried out through the market place is expected to be able to increase MSME sales.

Based on DBS Group Research [2], e-Commerce in Asia Bracing for Digital Disruption (2015) shows that the reason consumers do not like shopping online is because of several main reasons, namely fraud committed by sellers, security when making online payment transactions and other reasons, namely trust and quality of products will be sent by the seller. Consumer fears about online transactions have a negative impact on sales. DBS Group believes that those who correct their fears about online shopping will be able to develop and will continue to exist in online transactions.

The development of the internet is so rapid that all corners of the country, the development and improvement of infrastructure continues to be carried out by the government and MSMEs currently have great opportunities to utilize market places that can currently help to connect MSMEs with prospective buyers from all regions. In connection with the availability of the current market place, how SMEs are increasingly motivated to become entrepreneurs. This research aims to find out the motivation of SMEs to make online sales to improve business performance.

\section{Literature Review}

\subsection{Motivation}

Based on DBS Group Research [2], e-Commerce in Asia Bracing for Digital Disruption (2015) shows that the reason consumers do not like shopping online is because of several main reasons, namely fraud committed by sellers, security when making online payment transactions and other reasons, namely trust and quality of products will be sent by the seller. Consumer fears about online transactions have a negative impact on sales. DBS Group believes that those who correct their fears about online shopping will be able to develop and will continue to exist in online transactions.

The development of the internet is so rapid that all corners of the country, the development and improvement of infrastructure continues to be carried out by the government and MSMEs currently have great opportunities to utilize market places that can currently help to connect MSMEs with prospective buyers from all regions. In connection with the availability of the current market place, how SMEs are increasingly motivated to become entrepreneurs.

\subsection{Theory of Entrepreneurship}

McClelland in Sumarsono [3] said that the main psychological activator that motivates entrepreneurs is the need for achievement, which is usually identified as N Ach. David Mc Clelland in Sumarsono [3] identified a correlation between the behavior of people who have high achievement motives and entrepreneurial behavior. Entrepreneurial behavior manifested 
in attitudes and motivations towards successful careers and achievements is reflected in the following actions:

a) Example of people who are successful in the same field of work, adapting techniques to achieve success.

b) Use change to motivate yourself.

c) Action oriented.

d) High responsibility in the success of an activity.

e) Success is determined by the achievements of human data sources in the company.

f) Oversee that decisions are carried out properly and do not regret past failures.

Frederick Herzberg in Hasibuan [4] suggested a theory of motivation based on the theory of two factors, namely hygiene and motivator factors. Herzberg stated that people in carrying out their work are influenced by two factors that are needs, namely: 1. Maintenance Factors Is the maintenance factors associated with the nature of humans who want to gain physical tranquility. This health need is an ongoing need, because these needs will return to zero after being met. 2. Motivation Factors Is a motivating factor that involves a person's psychological needs that is the perfect feeling of doing work. This motivational factor is related to personal appreciation that is directly related to work. As for what is a motivational factor according to Herzberg are: the work itself (the work itself), achievements achieved (achievements), opportunities for progress (advancement), recognition of others (recognition), responsibility (responsible).

According to Herzberg hygienic factors (extrinsic) factors will not encourage employees' interest to perform well, but if these factors are deemed unsatisfactory in various ways such as inadequate salary, unpleasant working conditions, they can be a source of dissatisfaction potential [5]. While the motivation factor (intrinsic) factor is a factor that encourages enthusiasm in order to achieve higher performance. So gratification of high-level needs (motivational factors) allows one to perform higher than satisfying lower (hygienic) needs [6].

From Herzberg's theory, money/salary is not included as a motivating factor and this has been criticized by experts. Blue collar work is often done by them not because of intrinsic factors that influence entrepreneurship motivation Factors that influence entrepreneurship motivation are as follows [7]:

a) Confidence that is having a strong belief in the power that is in itself.

b) Innovative is a creativity that is implemented and provides added value to the resources we have and creative are things that have not been thought of by others.

c) Having a leadership spirit which is an important factor in influencing performance.

d) Effective and efficient. Effective is a job that can be completed on time, in accordance with a predetermined plan. In other words, effective is to what extent the goal has been achieved in terms of quality and quantity. Efficient is the best comparison between input and output, between business power and results of operations, or between expenditure and income. In other words, efficiency is everything that is done efficiently or everything can be resolved appropriately, quickly, economically and safely.

e) Future oriented. This means being able to see opportunities. Such individuals always look forward and will not question what was done yesterday, but rather question what will be done tomorrow 


\subsection{The Entrepreneurial Marketing Dimension}

a) Pro-activeness

Proactive is the most important behavior in the existence of human life, namely the ability of individuals to determine the meaning of life and struggle to fulfill the meaning of life as a personal responsibility. Proactivity has been characterized as an action taken to influence the company environment [8].

b) Focus on Opportunities

Many businesses that develop and develop rely on business opportunities as a result of an economic activity that arises. The introduction and search of marketing opportunities are important actions in the success of SMEs, market potential is generally evaluated by the level of suitability relative to the capabilities and resources of the company. The indicators used are able to meet the needs of consumers or the market, has a competitive advantage, is not temporary, can be valued with money and meets aspects of creativity and innovation that are solutions [9].

c) Risk Taking

Risk taking leads to unified behavior and can produce harmful or harmful decisions; at the same time, it can produce positive opportunities. The key is how perfect information is obtained. The more perfect the information collected and the more accurate the risk is obtained [9].

Business Success Definition of Business Success According to Lestari in Suryana [10] is the success of business in achieving its goals. Business success is essentially the success of the business achieving its goals. According to Nasution [11] a company is said to achieve business success if its business funds increase, production results increase, profits increase, the velocity of funds grows quickly and the income of members of the company increases. According to Ranto [12] the success of entrepreneurship is not identical with how successful a person collects money or wealth and becomes rich, because wealth can be obtained in various ways so as to produce added value.

\section{Methodology}

This research is analytical descriptive type which aims to find out the motivation of SMEs to make online sales to improve business performance. As the unit of analysis in this study is the Micro, Small and Medium Enterprises (SMEs). This research focuses on the motivation of SMEs to sell online to improve business performance. Primary data, in this study primary data were obtained from the results of in-depth interviews with key person selected for SMEs who sell products online. Shanty as owner of coconut milk coffee as a key person. Secondary data, obtained from documents, regulations and other forms that can provide information related to this research. The results of in-depth interviews with the key person of SMEs who sell products online.

\section{Results and Discussion}

Coffee businesses run by MSMEs can increase sales after doing online. The comparison that can be done is before making online sales, the real comparison that can be seen is the sale 
of coffee products which initially only sold $30 \mathrm{~kg}$ a month and increased to $300 \mathrm{~kg}$, about 10 times the initial sales. This shows that the power of going online is a very significant one to increase sales, especially for MSMEs.

In-depth interviews with key informants can give an idea to other SMEs to use the market place as an effective means to market products. Based on information from key informants, before using the market place the buyer is only the Blora community. The use of market place as a marketing tool is increasing the number of buyers from many regions such as Semarang, Medan, Jakarta, Bali, Samarinda and other cities.

Some market places that are used for activities to market products are Shopee, Tokopedia, Bukalapak, and Lazada. The beginning of marketing is only through word of mouth to market coffee products that are owned but according to the development of technology especially social media and market place to help SMEs to continue to develop their business. The beginning of the business which was pioneered only one district has now developed a national scale.

One of the advantages of this coffee is the uniqueness of coconut coffee that does not exist in other areas. Coconut milk coffee is a typical Blora coffee which is only produced in Blora Regency. Coconut milk coffee that is produced is a characteristic of the Blora area and makes Blora the only Coconut milk coffee place to date. Coffee is a bit strange for some people not only buyers in Indonesia but also foreign buyers, the main reason is because coffee is very strange when mixed with coconut milk but this Coconut milk Coffee is unique because it contains coconut milk.

Currently, there are several strategies to increase sales besides using market places such as promotion, which is to provide information to consumers that coconut milk coffee is safe even though it contains fat. Many prospective buyers ask for security, especially the impact on health by consuming coffee because it contains fat. Worried prospective buyers who doubt the security of this coffee even get the same response from prospective overseas buyers. Coconut milk coffee product packaging is one of the obstacles faced by SMEs because when potential buyers want to make a coffee purchase and search for a market place search engine, the first thing they notice is the appearance or packaging of the product. The first look at the product must give a positive impression to prospective buyers while the SMEs have weaknesses in designing packaging.

The current packaging of some products is still very simple although some are already good because they have received knowledge assistance from the Trade Office. According to Roddriguez [4] packaging is to install tools to maintain product quality and maintain product security. According to Wijayanti [13], packaging is a way for companies to provide product information to consumers, be it the production code, expiration date, nutritional information, product weight, taste and other information that consumers need to know. In accordance with the results of interviews with SMEs that so far, they have not paid attention to the information on the packaging even though many consumers ask for product information.

Financial limitations are one factor that is an obstacle for SMEs. Businesses that continue to grow and increase sales from a market place are not matched by the financial capabilities of SMEs. Market place has a very good and positive influence on the increase in sales of MSME players but does not match the financial capabilities of MSME entrepreneurs. 


\section{Conclusion}

Research on the role of market place in increasing MSME sales can be concluded:

a) Micro, small and medium businesses have very good benefits on increasing sales volume.

b) Through the market place coffee products can be sold nationally or internationally. Not only limited to Blora district.

c) SMEs are greatly helped by the presence of distributors in various regions to increase public awareness, especially coffee lovers.

d) UMKM players continue to develop packaging, products and assistance to increase the distribution of information about coconut milk carried out by the Central Java Provincial Trade Office.

\subsection{Suggestion}

From the results of the research conducted, suggestions were given, including:

a) UMKM businesses must continue to develop or add market places to increase public awareness of coconut milk products.

b) MSMEs must provide photos of more professional products to be posted on the market place.

c) SMEs continue to improve product quality and packaging improvements.

d) The Trade Service must continue to provide assistance until MSMEs become more professional and provide sharing opportunities with other business actors to increase the number of MSMEs in Central Java.

\section{References}

[1] APJII, "Buletin Asosiasi Penyelenggara Jasa Internet Indonesia," 2018.

[2] DBS Group Research, "E-Commerce in Asia, Bracing for Digital Disruption," 2015. .

[3] S. Sumarsono, Kewirausahaan. Yogyakarta: Graha Ilmu, 2010.

[4] S. P. H. Malayu, Organisasi dan Motivasi. Jakarta: PT. Bumi Aksara, 2008.

[5] D. Cushway, Barry; Lodge, Organisational Behaviour and Design, Perilaku dan Desain Organisasi. Jakarta: PT. Elex Media Komputindo, 1995.

[6] D. Timpe, Motivasi Pegawai. Jakarta: Gramedia Pustaka Utama, 1999.

[7] Tuskeroh, "Pengaruh Motivasi dan Mental Berwirausaha pada Mahasiswa Akuntasnsi Universitas Maritim Raja Ali Haji,” J. Akunt., pp. 1-17, 2013.

[8] T. S. Bateman and J. M. Crant, "The proactive component of organizational behavior: A measure and correlates," J. Organ. Behav., vol. 14, no. 2, pp. 103-118, 1993.

[9] Hendro, Dasar-Dasar Kewirausahaan. Jakarta: Erlangga, 2011.

[10] Suryana, Kewirausahaan, Pedoman Praktis, Kiat dan Proses Menuju Sukses. Jakarta: PT. Salemba Empat, 2003.

[11] B. Nasution, Keterbukaan dalam pasar modal. Universitas Indonesia, Fakultas Hukum, Program Pascasarjana, 2001.

[12] B. Ranto, "Korelasi antara Motivasi, Knowledge of Entreprenurship dan Independensi dan The Entrepreneur's Performance pada Kawasan Industri Kecil,” Manaj. Usahaw. Indones., vol. 36, no. $10,2007$.

[13] T. Wijayanti, “Marketing Plan! Perlukah,” Jakarta Elex Media Komputindo, 2012. 